Отримано: 15 травня 2018 р.

Прорецензовано: 21 травня 2018 р.

Прийнято до друку: 28 травня 2018 р.

e-mail: pysmennyi@i.ua

DOI: $10.25264 / 2311-5149-2018-9(37)-157-161$
Письменний В. В. Історичний досвід організації самооподаткування на території сучасної української держави. Наукові записки Наиіонального університету «Ocmрозька академія». Серія «Економіка» : науковий журнал. Острог : Вид-во НаУОА, червень 2018. № 9(37). С. 157-161.

Письменний Віталій Валерійович,

кандидат економічних наук, дочент, докторант кафедри фінансів ім. С. І. Юрія,

Тернопільський національний економічний університет

\title{
ІСТОРИЧНИЙ ДОСВІД ОРГАНІЗАЦІЇ САМООПОДАТКУВАННЯ НА ТЕРИТОРІЇ СУЧАСНОЇ УКРАЇНСЬКОЇ ДЕРЖАВИ
}

У статті вивчено історичний досвід організації самооподаткування на території сучасної української держави, платежі якого могли стягуватися у грошовій формі та додатково накладатися на селян як натуральні повинності. Проаналізовано особливості самооподаткування в радянський період, яке проводили без будь-якого плану, його неврегульованість призводила до різних форм стягнення зборів, ігнорувався принцип індивідуальної добровільності, а витрачання коштів було безконтрольним. Визначено бар'єри, які сьогодні гальмують поширення практики самооподаткування в Україні.

Ключові слова: місиеві бюджети, фінансове забезпечення місиевого самоврядування, бюджетні доходи, самооподаткування.

\section{Письменный Виталий Валериевич, \\ кандидат экономических наук, доцент, докторант кафедры финансов им. С. И. Юрия, Тернопольский начиональный экономический университет \\ ИСТОРИЧЕСКИЙ ОПЫТ ОРГАНИЗАЦИИ САМООБЛОЖЕНИЯ НА ТЕРРИТОРИИ СОВРЕМЕННОГО УКРАИНСКОГО ГОСУДАРСТВА}

В статье изучен исторический опыт организачии самообложения на территории современного украинского государства, платежи которого могли взиматься в денежной форме и дополнительно накладьваться на крестьян как натуральные повинности. Проанализированы особенности самообложения в советский период, которое проводилось без всякого плана, его неурегулированность приводила к различнылм формам взимания сборов, игнорировался принцип индивидуальной добровольности, а расходование средств было бесконтрольным. Определены барьеры, которые сегодня тормозят распространение практики самообложения в Украине.

Ключевые слова: местные бюджеты, финансовое обеспечение местного самоуправления, бюджетные доходы, самообложения.

Vitaliy Pysmennyi,

Ph.D. in Economics, Assistant Professor, Doctoral Student at the Department of Finance named after S. I. Yuriy,

Ternopil National Economic University

\section{HISTORICAL EXPERIENCE OF SELF-TAXATION ORGANIZATION ON THE TERRITORY OF THE MODERN UKRAINIAN STATE}

The article deals with the historical experience of self-taxation organization on the territory of the modern Ukrainian state. The taxes under study were collected in cash and additionally imposed on peasants as natural duties. The features of the self-taxation development in the Soviet period were analyzed. It was found that self-taxation was carried out without any plan, its unsettledness led to various forms of collection, the principle of individual voluntariness was ignored, and the spending of funds was uncontrolled. The barriers that today impede the spread of the self-taxation practice in Ukraine are identified.

Key words: local budgets, financial support of local self-government, budget revenues, self-taxation.

Постановка проблеми. Самооподаткування - одна 3 найсуперечливіших форм фіскальних відносин на селі, вивчення якої ось уже понад півтора століття не полишає панелі історико-економічної дискусії. На території сучасної української держави воно виникло із зародженням перших самоврядних одиниць $\mathrm{i}$ протрималося в тому чи іншому вигляді до наших днів. Дослідження самооподаткування в генезисі важливе тим, що дасть змогу побачити його прогалини й колізії в законодавстві, усунути елементи хаотичності та дивергенції в організації, побудувати новий алгоритм добровільної участі громадян грошовими засобами в заходах з упорядкування та соціально-культурного розвитку сільських населених пунктів. 
Аналіз останніх досліджень і публікацій. Теоретичні аспекти самооподаткування можна простежити в літературі авторів дорадянського та радянського часів Д. П. Боголєпова [1], Д. В. Данілова [2], І. М. Кулішера [3], М. Л. Леонтьєва [4], М. І. Мітіліно [5], І. Х. Озерова [6], В. М. Твердохлєбова [7], I. I. Янжула [8] й інших. У цьому сенсі зацікавлюють праці наших сучасників В. Г. Дем'янишина [9], В. В. Зайчикової [10], О. П. Кириленко [11], В. І. Кравченка [12], О. А. Музики-Стефанчук [13], С. І. Юрія [14] та інших. 3-поміж контроверсійного бачення розвитку або скасування самооподаткування, їхні погляди співпадають у тому, що воно не розв'язує проблему бюджетної самодостатності, забезпечуючи лише мобілізацію факультативних джерел доходів місцевих бюджетів.

Метою дослідження $\epsilon$ вивчення історичного досвіду самооподаткування, виявлення проблем цієї форми фіскальних відносин і вироблення парадигми добровільної участі громадян грошовими засобами в заходах з упорядкування і соціально-культурного розвитку сільських населених пунктів.

Виклад основного матеріалу. Після проведенням земської реформи на території сучасної української держави царська влада, не зумівши впоратися з фінансовими труднощами, які лягали на їі плечі, перекладала багато функцій загального характеру на місця. Як зазначав тодішній економіст і політичний діяч Д. П. Боголєпов, за земський рахунок утримували тюрми, розквартирували війська та чиновників, будували і ремонтували дороги місцевого й загальнодержавного значення [1, с. 208]. 3 появою перших ознак місцевого самоврядування держава мала би фінансово підтримати ініціативи місцевої влади у формуванні самодостатніх бюджетів, а не прикриватися делегуванням компетенції зі самооподаткування.

Поряд із грошовими зборами розповсюдженою була практика накладання натуральних повинностей. Водночас загальне навантаження розподіляли між селянськими господарствами нерівномірно та воно не залежало від їхньої податкоспроможності, а саме розміру посіву, кількості десятин землі, чисельності голів худоби тощо [4, с. 83]. За дослідженням О. В. Борисюка, механізм самооподаткування був настільки парадоксально побудований, що належні до сплати платежі обернено пропорційно відповідали розміру території, а саме: «Менша за розміром земельна громада сплачувала більший платіж, і навпаки, чим більшою вона була, тим менший розмір сплачувала» [15, с. 83$]$.

Через дріб'язковість фіскальних результатів і вагомі адміністративні витрати, конструювання самооподаткування в системі державних фінансів було недоцільним. В. О. Лебедєв пояснював це тим, що, користуючись перевагою, держава охороняє своє, а місцева влада змушена задовольнятися залишками [16, с. 54]. Крім опіки над місцями, тоді було поширене поліцейське свавілля. Одне з них - згадувані натуральні повинності, які виконували селяни додатково до податків у грошовій формі. Гасити пожежі, ремонтувати дороги, возити чиновників - усе це стосувалося натуральних повинностей. У не земських губерніях, де цими функціями опікувалася поліція, гроші «клала собі в кишеню», а на їх виконання стягувала мешканців сіл [1, с. 212].

Однією з перших спроб регламентації самооподаткування в радянській державі стало прийняття в серпні 1924 р. законодавчого акта «Про самооподаткування населення для задоволення місцевих суспільних потреб». Згідно з ним справляння платежів допускалося на добровільних засадах, а їх надходження спрямовувалися на упорядкування населених пунктів, утримання навчальних закладів, лікарень й інші заходи, на які не вистачало доходів місцевих бюджетів. Водночас участь волостних виконавчих комітетів і сільських рад у проведенні самооподаткування заборонялася. Усі проблеми мали розв'язуватися тільки в судовому порядку при тому, що використання якихось адміністративних дій не допускалося.

Заразом у книзі «Низовий бюджет і суспільне господарство на селі» за редакцією М. Л. Леонтьєва автори більш прагматично розкрили це явище, акцентуючи увагу на недоліках (рис. 1). У багатьох випадках самооподаткування не було цільовим, призводило до розпорошення та непродуктивного використання коштів. Усунення фінансових органів, волосних і сільських рад під час його проведення призводило до безгосподарських і безконтрольних видатків. Тому тоді було складно встановити, скільки саме було зібрано коштів і на які цілі їх використовували (судячи за окремими даними, вони досягли вельми значних розмірів - понад 100 млн крб [4, с. 84$])$.

Попри те, що парадигма самооподаткування в радянській державі була зумовлена недостатніми асигнуваннями з місцевих бюджетів, у низці випадків воно проводилося безконтрольно та не піддавалося обліку. Про справляння зборів, їх види та кількість селяни дізнавалися в останній момент, тому здійснювався великий супротив надмірного та подекуди несправедливого податкового навантаження. У багатьох сільських населених пунктах ігнорували принцип індивідуальної добровільності, через що оподатковували всіх мешканців. Але найбільше дестимулювало розвиток несправедливість, оскільки витрачання коштів проводилося тими ж особами, що їх збирали й зазвичай без звітності та належного контролю.

Хоча, згідно з тодішнім законодавством, у разі виявлення фактів його порушення контролюючі органи були зобов'язані зробити відповідні розпорядження щодо заборони справляння платежів зі самооподаткування та притягнути винних осіб до кримінальної відповідальності. Інші законодавчі ініціативи із цієї форми мобілізації фінансових ресурсів проявилися в січні 1928 р. у частині прийняття законодавчого акту, що регламентував самооподаткування сільського населення на задоволення його колективних по- 
треб. На відміну від податків, ці платежі були класовими, а шкала їх ставок будували за принципом арифметичної прогресії залежно від доходів господарств.

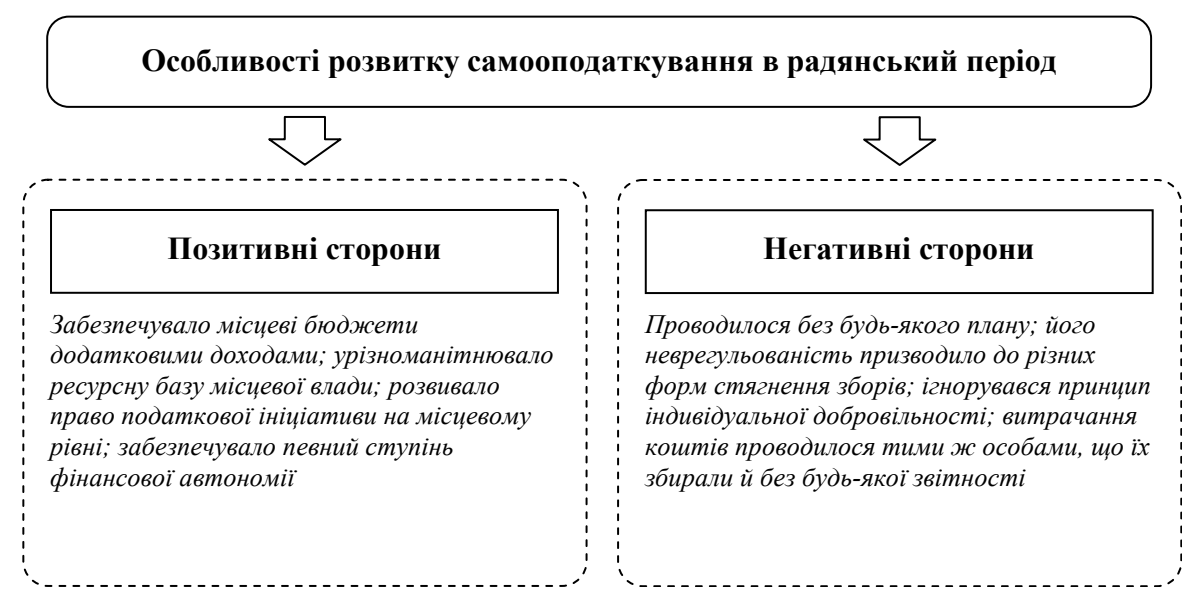

Рис. 1. Особливості розвитку самооподаткування в радянський період

Примітка. Побудовано автором на основі [4, с. 87].

Наприклад, господарство з доходом у сумі 200 крб вносило один пай, із доходом на суму 600 крб - 13 паїв, із доходом на суму 1200 крб - 46 паїв тощо [17]. Відтак основна частина загального обсягу надходжень (а це приблизно 30 млн крб) була стягнена зі заможних верств селянства. Внаслідок такого навантаження впродовж другої половини 1920-их рр. кількість селянських господарств, які використовували у власному господарстві сторонню робочу силу, скоротилася вдвічі, а їхні посіви зменшилися на майже 20 \%. Проте здебільшого вітчизняні вчені-історики згадані цифри пов’ язують радше з дискримінаційною економічною політикою радянської держави, аніж із неефективністю самооподаткування сільського населення.

Фактично до 1933 р. сільськогосподарський податок був найпоширенішою формою мобілізації фінансових ресурсів, стягнення якого здійснювалося за допомогою адміністративно-примусових методів. Поряд із ним була специфічна форма селянських повинностей - самооподаткування. Передбачалося, що сума цих платежів не мала перевищувати 35\% від розміру єдиного сільгоспподатку, щоправда, iї постійно переглядали. Ставки платежів зі самооподаткування, тобто надподатку щодо єдиного сільськогосподарського податку, становили 70-100\%. Водночас райфінвідділи раз у раз вимагали від сільських рад збільшувати обсяги таких надходжень.

Надалі реалізація самооподаткування регламентувалася Постановою ЦВК СРСР і РНК СРСР «Про самообкладання сільського населення». Його особливостями стало таке: по-перше, самооподаткування здійснювалося в сільській місцевості відповідно до рішення загальних зборів громадян селища або кількох селищ; по-друге, кошти не включалися до бюджету, а витрачалися на будівництво та ремонт доріг, мостів, шкіл, лікарень тощо; по-третє, заборонялося вилучати надходження зі самооподаткування вищими органами влади; по-четверте, передбачалося оприлюднення фінансового звіту про використання коштів від самооподаткування сільської ради перед загальними зборами громадян [18, с. 44].

У післявоєнний період зі згортанням фінансової незалежності місцевого самоврядування або, як вказував В. І. Кравченко, процесом «демонтажу місцевих фінансів» [12, с. 28] самооподаткування населення в сільській місцевості було фактично пригальмовано, хоча в деяких населених пунктах існувало напівлегально. Тільки на початку 1980-их рр. для залучення додаткових коштів для фінансування заходів із упорядкування і соціально-культурного розвитку сільських населених пунктів було прийнято Указ Президії Верховної Ради Української РСР «Про самооподаткування сільського населення», який законодавчо врегулював функціональний механізм цієї форми мобілізації фінансових ресурсів.

Згідно з положеннями Указу організацію самооподаткування сільського населення було доручено сільським радам народних депутатів, а рішення щодо його проведення - загальним зборам або сходу громадян, котрі проживають у населеному пункті [19]. Водночас виконавчі комітети сільських рад народних депутатів мали забезпечити надходження сум платежів зі самооподаткування, своєчасну здачу коштів до кредитно-розрахункових установ, проведення заходів з упорядкування і соціально-культурного розвитку сіл. До речі, цей нормативно-правовий документ досі не втратив юридичної сили та використовується місцевими радами в сучасній українській державі як законодавче підгрунтя для прийняття відповідних рішень. 
До позитивних ознак Указу про самооподаткування можна віднести порядок, відповідно до якого декілька сільських рад мали право здійснювати спільні заходи за рахунок платежів зі самооподаткування. Кожна рада, яка брала участь у таких заходах, повинна була прийняти відповідне рішення, однак через недотримання на практиці, це положення було декларативним. Доречно зауважити й те, що, будучи добровільною формою мобілізації фінансових ресурсів, воно виявилося занадто обтяжливим і носило не добровільний, а примусовий характер [15, с. 748]. Це чи не найбільша вада самооподаткування, якої не вдалося позбутися за увесь період українського державотворення і потребує усунення.

У «Словнику української мови» подано детальне пояснення цих слів, що можна інтерпретувати у світлі самооподаткування. «Добровільний» означає, який здійснюється, діє з власного бажання, без примусу або який існує на основі самодіяльності мас, завдяки підтримці громадськості [20, с. 324]. В Указі про самооподаткування йдеться про те, що рішення загальних зборів громадян про проведення самооподаткування $є$ обов'язковим для всіх громадян, які проживають у населеному пункті, його частині або в декількох населених пунктах, де відбулися загальні збори громадян [19]. Тут же годиться слово «примусовий» - який спричиняється обставинами, не залежний від бажання [21, с. 682].

У наші дні питання самооподаткування в бюджетному та податковому законодавствах навіть не розглядаються. Лише в Законі України «Про місцеве самоврядування в Україні» дається йому визначення як форми залучення на добровільній основі за рішенням зборів громадян за місцем проживання коштів населення відповідної території для фінансування разових цільових заходів соціально-побутового характеру [22]. Якщо в пп. 9.4 ст. 9 і пп. 10.4 ст. 10 Податкового кодексу України йдеться про заборону встановлювати податки, не передбачені ним, то ст. 92 Конституції України гласить, що вони можуть бути встановлені законами. Якраз згадкою в Законі про місцеве самоврядування користуються місцеві ради, впроваджуючи «свої» платежі.

Висновки. Отже, не дивлячись на всі вади, оглянуті в історичному контексті, повноцінне поширення практики самооподаткування в сучасній українській державі гальмується через: по-перше, відсутність нормативно-правового документа, який регламентував би механізм справляння відповідних платежів; по-друге, брак кваліфікованого персоналу, переважно в сільських населених пунктах, який здатний реалізувати алгоритм самооподаткування від початку до завершення; по-третє, нецільове спрямування та неефективне використання надходжень; по-четверте, низьку добровільність сплати, спричинену поганою поінформованістю щодо необхідності використання цієї форми мобілізації фінансових ресурсів.

Згадані проблеми не виникли одномоментно, а тягнуться ось уже понад півтора століття, вносячи елементи хаотичності та дивергенції в організацію самооподаткування. Їх розв'язання в наступних публікаціях дасть змогу побудувати новий алгоритм добровільної участі громадян грошовими засобами в заходах з упорядкування та соціально-культурного розвитку сільських населених пунктів. Для них інструменти самооподаткування є найбільш прийнятними, оскільки сприяють залученню додаткових коштів для фінансування цільових заходів. Водночас поширення цієї форми фіскальних відносин і вдосконалення механізму справляння забезпечить зміну статусу факультативного джерела бюджетних доходів.

\section{Література:}

1. Боголепов Д. Краткий курс финансовой науки. Москва: Изд-во «Пролетарий», 1925. 281 с.

2. Данилов Д. В. Местные налоги и рента. Москва: Государственное финансовое Изд-во Союза ССР, 1930. $87 \mathrm{c}$.

3. Кулишер И. М. Очерки финансовой науки. Петроград: Изд-во «Наука и школа», 1919. 252 с.

4. Бурцев Е. К., Кочинов Г. И., Чистовский Н. В. Низовой бюджет и общественное хозяйство в деревне / под ред. М. Л. Леонтьева. Москва: Гос. фин. изд-во Союза ССР, 1929. 119 с.

5. Мітіліно М. І. Основи фінансової науки. Київ: Держ. вид-во України, 1929. 395 с.

6. Озеров И. Х. Основы финансовой науки. Москва: Тип. т-ва И. Д. Сытина, 1914. 364 с.

7. Твердохлебов В. Н. Новейшие финансовые проблемы (1914-1923 гг.). Петроград, 1923. 160 с.

8. Янжуль И. И. Основныя начала финансовой науки. Ученіе о государственныхъ доходах. Санкт-Петербург, 1904. $499 \mathrm{c}$.

9. Дем'янишин В. Г. Теоретична концептуалізація і практична реалізація бюджетної доктрини України: монографія. Тернопіль: ТНЕУ, 2008. 496 c.

10. Зайчикова В. В. Місцеві фінанси України та європейських країн: монографія. Київ: НДФІ, 2007. 299 с.

11. Кириленко О. П. Місцеві бюджети України (історія, теорія, практика): монографія. Київ: НIOC, 2000. $384 \mathrm{c}$.

12. Кравченко В. І. Місцеві фінанси України: навч. посіб. Київ: Т-во «Знання», КОО, 1999. 487 с.

13. Музика-Стефанчук О. А. Фінансово-правова основа місцевого самоврядування в зарубіжних країнах: навч. посіб. Київ: Правова єдність, 2009. 224 с.

14. Юрій С. І. Фінансова парадигма місцевого самоврядування. Світ фінансів. 2004. Вип. 1. С. 6-14.

15. Борисюк О. В. Самооподаткування в Україні: історичні витоки та проблеми адміністрування. Глобальні та найінальні проблеми економіки. 2016. Вип. 10. С. 745-750. 
16. Лебедев В. А. Местные налоги. Опыт исследования теории и практики местного налогообложения. Санкт-Петербург: Тип. А. М. Вольфа, 1886. 583 с.

17. Шитюк М. Наслідки колективізації на Миколаївщині. URL: http:/www.history.org.ua/zbirnyk/problems/10. pdf (дата звернення: 11.02.2010).

18. Буряченко А. С. Самооподаткування як резерв зростання бюджетів місцевого самоврядування. Фінанси України. 2009. № 2. С. 44-50.

19. Указ Президії Верховної Ради Української РСР «Про самооподаткування сільського населення» від 23.04.1984 № 6853-Х. Відомості Верховної Ради УРСР. 1984. № 19. Ст. 364.

20. Словник української мови. В 11 т. Т. 2: Г-Ж / ред. П. П. Доценко, Л. А. Юрчук. Київ: Наук. думка, 1971. $550 \mathrm{c}$.

21. Словник української мови. В 11 т. Т. 7: П / ред. О. П. Петровська, М. М. Пилинський, Л. О. Родніна, Н. І. Швидка. Київ: Наук. думка, 1976. 727 с.

22. Закон України «Про місцеве самоврядування в Україні» від 21.05.1997 № 280/97-ВР. Вiдомості Верховної Ради України. 1997. № 24. Ст. 170. 